\title{
Response of Triacontanol on Temperate Fruit Crops - A Review
}

\author{
M.K. Sharma*, Amarjeet Singh, A. Kumar, S.A. Simnani, N. Nazir, \\ A. Khalil, R. Mushtaq and R. Bhat
}

Division of Fruit Science, Sher-e-Kashmir University of Agricultural Sciences \& Technology of Kashmir, Shalimar, Srinagar (J\&K.), India

*Corresponding author

\section{A B S T R A C T}

\section{Keywords \\ Growth regulators, Growth, Water relations, Nutrient uptake \\ Article Info \\ Accepted: 26 October 2018 Available Online: 10 November 2018}

\section{Introduction}

Triacontanoll (TRIA), is a natural plant growth regulator found in plant cuticular waxes and bee wax. It is a straight chain 30 carbon alcohol i.e. primary alcohol is an endogenous hormone which is active at very low concentration on the cell membranes and acts in combination with other long chain alcohols to regulate the formation of TRIM, a secondary messenger(s) of TRIA.

TRIM, the putative secondary messenger elicited by TRIA, move rapidly throughout the plant resulting in dry matter increase (Ries and Wert, 1988). Triacontanol is reported to improve growth, photosynthesis, transpiration, stomatal conductance and uptake of water and nutrients and other metabolic activities in different crops (Krishnan and Kumari, 2008).

Application of triacontanol applied either to the leaves or to root medium influence different physiological activities in different fruit crops. They also improve plant performance under adverse conditions.

Therefore the use of triacontanol is increasing day by day in different fruit crops to influence different plant responses. Presently its use is also picking up in temperate fruit crops. Therefore the present review covers the response of traicontanol on plant growth, water relations and leaf nutrient status in different temperate fruit crops. 


\section{Effect on plant growth and vigour}

Markedly higher annual shoot growth was observed in Santa Rosa plum with the $10 \mathrm{ppm}$ triacontanol (Barua, 1990) and in Red Delicious apple with $0.75 \mathrm{ml}^{-1}$ Miraculan (Sharma, 1990). Growth and size of Japanese plum were increased when sprayed with triacontanol (Chandel, 1985). Improved growth with triacontanol has also been observed in New Castle apricot (Mahajan et al., 1988). Red Delicious apples treated with $0.6 \mathrm{ml} \mathrm{1}^{-1}$ Paras Photosynth (Sharma, 1990) had the maximum leaf area. Similarly, leaf growth and petiole length in Golden Delicious apples increased on treatment with Agrispon (triacontanol) twice, 3 weeks after flowering and 10-15 days later (Dubravec et al., 1995). Size and dry weight of apricot leaves increased with the application of Miraculan and Vipul (Mahajan et al., 1988). Similarly, Barua (1990) recorded higher leaf area in Santa Rosa plum on treatment with 5 ppm triacontanol.

Sharma and Joolka (2002) reported more annual extension growth, plant height and spread in Non Pareil almond treated with 10 ppm triacontanol in comparison to other treatments. Joolka and Sharma (2003) observed better shoot growth in apricot cv. New Castle with 5 ppm triacontanol applied once at 15 days before floweing and repeated at pit hardening stage. Tomar and Singh (2007) reported maximum tree height, trunk girth, shoot growth and tree volume with triacontanol in walnut cv. Local Selection.

Sharma et al., (2008 a) applied triacontanol at 2.5, 5.0, 7.5 and $10.0 \mathrm{ppm}$ thrice, viz., 7 days before full bloom, 15 days after full bloom and one month after second application in apple cv. Red Delicious and observed that application of $7.5 \mathrm{ppm}$ triacontanol increased shoot extension growth in comparison to other triacontanol treatments. Sharma et al.,
(2008 b) and Wangmo et al., (2008) observed that application of triacontanol was most effective in promoting tree growth in Santa Rosa plum.

\section{Effect on root growth}

Tantos et al., (2001) argued that the provision of triacontanol could increase the number of roots per plant.

\section{Effect on chlorophyll content}

Leaf chlorophyll content increased in Santa Rosa plum after treatment with $2.5 \mathrm{ppm}$ triacontanol (Barua, 1990), in Red Delicious apple with $0.6 \mathrm{ml}^{-1}$ Paras Photosynth (Sharma, 1990) and in Elstar and Golden Delicious apples with Agrispan (triacontanol) (Dubravec et al., 1995). Sharma and Joolka, (2000) also reported increased leaf chlorophyll content in Non Pareil almond with $10 \mathrm{ppm}$ triacontanol.

\section{Effect on photosynthesis, transpiration and stomatal conductance}

Exogenous application of triacontanol regulates several physiological and biochemical processes directly or indirectly (Ries and Houtz, 1983). Photosynthetic rate increased in Santa Rosa plum after treatment with $2.5 \mathrm{ppm}$ triacontanol (Barua, 1990), in Red Delicious apple with $0.6 \mathrm{ml} 1^{-1}$ Paras Photosynth (Sharma, 1990) and in Elstar and Golden Delicious apples with Agrispon (triacontanol) (Dubravec et al., 1995). Sharma and Joolka (2000) also reported increased rate of photosynthesis, transpiration and stomatal conductance in Non Pareil almond with 10 ppm triacontanol. Rate of photosynthesis and transpiration was significantly affected by application of bioregulators and highest photosynthetic and transpiration rate was observed with the application of triacontanol $7.5 \mathrm{ppm}$ in apricot (Thakur, 2014). 


\section{Effect on carbohydrate content}

Shoots of Santa Rosa plum had highest carbohydrate content when treated with 5 ppm triacontanol (Barua, 1990). Sharma (1990) recorded highest total sugars, starch and carbohydrate contents in Red Delicious apple leaves with $0.75 \mathrm{ml}^{-1}$ Miraculan. Sharma et al., (2002) reported higher accumulation of leaf carbohydrates content in Non Pareil almond with $10 \mathrm{ppm}$ triacontanol.

\section{Effect on micropropagation}

The effectiveness of triacontanol woody plants have also been successfully investigated although in micropropagation i.e. via organo-genesis in plants of apples (Malus domestica cv. JTE-E4) and cherry (Cerasusfruticosa cv. Probocskai) (Tantos et al., 2001).

\section{Effect on nutrient uptake}

Triacontanol has been known to influence the nutrient levels in various fruit crops. Therefore, effect of triacontanol on the uptake of macro nutrients is reviewed under the following heads:

\section{Nitrogen}

$\mathrm{N}$ content increased in the leaves of Santa Rosa plum with $7.5 \mathrm{ppm}$ traicontanol (Barua, 1990), in Red Delicious apple with $0.75 \mathrm{ml} 1$

${ }^{1}$ Miraculan (Sharma and Joolka, 1994) and in Non Pareil almond with $10 \mathrm{ppm}$ triacontanol (Sharma and Joolka, 2011).

\section{Phosphorus}

Foliar sprays of $2.5 \mathrm{ppm}$ triacontanol or 10 ppm Miraculan resulted in highest leaf $\mathrm{P}$ content in Santa Rosa plum (Barua, 1990). Sharma and Joolka (1994) observed that Miraculan at $0.75 \mathrm{ml} \mathrm{l}^{-1}$ was most effective in raising the foliar $\mathrm{P}$ content in Red Delicious apple. Sharma and Joolka (2011) also reported increased leaf $\mathrm{P}$ content in Non Pareil almond with $10 \mathrm{ppm}$ triacontanol.

\section{Potassium}

Leaf $\mathrm{K}$ content was higher when Santa Rosa plum trees were sprayed with $2.5 \mathrm{ppm}$ triacontanol (Barua, 1990). Similarly, Sharma and Joolka (1994) observed that Miraculan at $0.75 \mathrm{ml}^{-1}$ was most potent in raising foliar $\mathrm{K}$ content of Red Delicious apples. Sharma and Joolka (2011) also reported increased leaf K content in Non Pareil almond with $10 \mathrm{ppm}$ triacontanol.

\section{Calcium}

Sharma and Joolka (1994) observed that among different chemicals studied, Miraculan at $0.75 \mathrm{ml}^{-1}$ was most effective in raising the foliar $\mathrm{Ca}$ content in Red Delicious apples. Sharma and Joolka (2011) also reported increased leaf $\mathrm{Ca}$ content in Non Pareil almond with $10 \mathrm{ppm}$ triacontanol.

\section{Magnesium}

Miraculan at $0.75 \mathrm{ml} \mathrm{1}^{-1}$ markedly raised the foliar $\mathrm{Mg}$ content in Red Delicious apples (Sharma and Joolka, 1994). Sharma and Joolka (2011) also reported increased leaf Mg content Non Pareil almond with 10 ppm traicontanol.

From the above review it can be concluded that traicontanol improves the growth and other physiological activities as well as leaf nutrient status in different temperate fruit crops. Foliar and soil application of triacontanol is very effective in improving plant response to various factors. However, further studies are required to reveal the possible role of triacontanol on the regulation of plant growth and other metabolic activities 
in different temperate fruit crops for its wider application.

\section{References}

Barua, S. C. 1990. Effect of triacontanol on growth and fruiting of plum cv. Santa Rosa. Ph. D. Thesis, Dr. Y. S. Parmar University of Horticulture and Forestry) Nauni, Solan, India.

Chandel, J.S. 1985. The effect of triacontanol and paclobutrazol (PP333) in combination with certain growth retardants on fruiting and quality of Japanese plum (Prunus salicina Lindl.). M.Sc. Thesis, Dr. Y.S. Parmar University of Horticulture and Forestry, Nauni, Solan, India.

Dubravec, K., Dubravec, I. and Manistasevic, J. 1995. The effect of the bioregulators Agrispon Rand Ergostim on the vegetative and reproductive growth of apples. J. Sust. Agric., 5(1-2): 73-83.

Joolka, N.K. and Sharma, M.K. 2003. Effect of triacontanol on growth, yield and quality of apricot. The Hort. Journal 16(1): 89-91.

Krishnan, R.R. and Kumari, B.D.R. 2008. Effect of N-triacontanol on the growth of salt stressed soybean plants. Journal of Biosciences. 19:53-62.

Mahajan, B.V.C., Parmar, C. and Sud, G. 1988. Effect of triacontanol on area and dry weight of apricot (Prunus armeniaca L.) leaves. National symposium on regulation of growth and differentiation in plants. March 21-23, Chandigarh.

Ries, S. and Houtz, R. 1983. Triacontanol as a plant growth regulator. HortSci. 18(5):654-662.

Ries, S.K. and Wert. V.F. 1988. Rapid elicitation of second messenger by nanomolar doses of triacontanol and octacosanol. Planta 173: 79':87.
Sharma, D.P. 1990. Effect of some bioregulators on growth, yield, fruit quality and nutrient status of apple. M.Sc. Thesis, Dr Y. S. Parmar University of Horticulture and Forestry, Nauni, Solan, India.

Sharma, D.P. and Joolka, N.K. 1994. Effect of some bioregulators on leaf nutrient content of apple cv. Red Delicious. Haryana J. Hort. Sci. 4:293-298.

Sharma, M.K. and Joolka, N.K. 2002. Growth and water relations of Nonpareil almond as influenced by growth regulators. The Hort. Journal 15(2): 83-86.

Sharma, M.K. and Joolka, N.K. 2011. Influence of triacontanol and paclobutrazol on growth and leaf nutrient status of Non Pareil almond under different soil moisture regimes. Indian Journal of Horticulture 68(2): 180-183.

Sharma, M.K. and Joolka, N.K. 2000. Influence of triacontanol and paclobutrazol on the drought tolerance of Nonpareil almond. Indian Journal of Horticulture 57(2): 118-121.

Sharma, M.K., Joolka, N.K. and Sharma, N.2002. Effect of triacontanol and paclobutrazol on photosynthetic efficiency, carbohydrates metabolism and leaf nutrient status of Nonpareil almond. Progressive Horticulture 43(1): 117-118.

Sharma, M.K., Farooqui, K.D., Bhat, K.M. and Singh, S.R. 2008 a. Effect of triacontanol on growth and yield of apple cv. Red Delicious under Kashmir valley conditions. Environment \& Ecology 26(2): 637-639.

Sharma, M.K., Wangmo, Kunzang, Singh, S.R. and Wani, M.S. 2008 b. Influence of $\mathrm{GA}_{3}, \mathrm{BA}, \mathrm{TRIA}$ and their combinations on tree vigour, production and chemical characteristics of Santa Rosa plum. Environment \& Ecology 26(4B): 2102-2104. 
Tantos, A., Meszaros, A., Farkas, T. and Szalai, J. 2001. Triacontanol-supported micro-propagation of woody plants. Plant Cell Reports 20: $16-21$.

Thakur, Kalpana. 2014. Effect of bioregulators and plant growth promoting rhizobacteria on growth, yield and quality of apricot (Prunus armeniaca L.) cv. New Castle. M.Sc. Thesis, Dr. Y.S. Parmar University of Horticulture and Forestry, Nauni, Solan (H.P.).
Tomar, C.S. and Singh, N. 2007. Effect of foliar application of nutrients and bioregulators on growth, fruit set, yield and nut quality of walnut. Indian Journal of Horticulture 64(7): 271- 273. 68.

Wangmo, Kunzang, Sharma, M.K. and Singh, S.R.2008. Effect of bio-regulators on tree growth, fruit yield and quality of plum (Prunus salicina Lindl.) cv. Santa Rosa under Kashmir valley conditions. Environment \& Ecology 26(4A): 17921794.

\section{How to cite this article:}

Sharma, M.K., Amarjeet Singh, A. Kumar, S.A. Simnani, N. Nazir, A. Khalil, R. Mushtaq and Bhat, R. 2018. Response of Triacontanol on Temperate Fruit Crops - A Review. Int.J.Curr.Microbiol.App.Sci. 7(11): 3239-3243. doi: https://doi.org/10.20546/ijcmas.2018.711.373 